УДК 616-057/616.24-008.4:616-071:001.5

\title{
ВЫЯВЛЕНИЕ АУСКУЛЬТАТИВНЫХ ПРИЗНАКОВ ХОБЛ С ПОМОЩЬЮ СТАТИСТИКИ ВЫСШИХ ПОРЯДКОВ ПРИ АНАЛИЗЕ ЗВУКОВ ДЫХАНИЯ
}

\author{
ПОРЕВА А. С. ${ }^{1}$, КАРПЛЮК Е. С. ${ }^{1}$, МАКАРЕНКОВА А. А. ${ }^{2}$, МАКАРЕНКОВ А. П. ${ }^{2}$ \\ ${ }^{1}$ Национальный технический университет Украины \\ «Киевский политехнический институт», \\ Украина, Киев, 03056, пр-т Победы 37 \\ ${ }^{2}$ Институт гидромеханики НАН Украинь, \\ Украина, Киев, 03680, ул. Желябова, 8/4
}

\begin{abstract}
Аннотация. Предложен метод определения характерных аускультативных диагностических признаков у больных ХОБЛ, основанный на использовании полиспектрального анализа и расчета статистик высшего порядка. Этапами метода являются расчет и построение функции бикогерентности сигнала звука дыхания для нахождения ее максимального значения. Визуальная и численная оценка полученного максимума позволяет сделать заключение о наличии или отсутствии в данном звуковом сигнале легкого артефакта, свидетельствующего о патологии. Для более точных результатов необходимо получить коэффициент асимметрии и выполнить оценку бичастоты, соответствующей максимальному значению коэффициента бикогерентности. Расчет коэффициентов асимметрии и эксцесса взаимокорреляционных функций сигналов звуков легких, снятых синхронно в четырех каналах, позволяет уменьшить чувствительность метода к шумовым составляющим. Таким образом, анализируя все предложенные рассчитанные характеристики и параметры, возможно принять решение о наличии или отсутствии в данном звуковом сигнале патологии
\end{abstract}

Ключевые слова: звуки легких; ХОБЛ; коэффициент бикогерентности; коэффициент ассимметрии; коэффициент эксцесса; бичастоты

\section{1. ВВЕДЕНИЕ}

Использование современных диагностических методов в практической медицине, позволяющих получать более точные данные о состоянии органов и систем организма человека, значительно расширяют возможности врачей выбирать оптимальные методы лечения. В последние годы широкое применение в медицине находят высокоинформативные методы обследования организма человека, в том числе, и электронная аускультация (регистрация, компьютерная обработка и визуализация звуков дыхания), которая позволяет выявлять и объективизировать характерные аускульта- тивные диагностические признаки заболеваний бронхолегочной системы.

Глобальная инициатива по хронической обструктивной болезни легких (ХОБЛ, chronic obstructive pulmonary disease, COPD) - совместный проект Института сердца, легких и крови (США) и ВОЗ [1] определяют ХОБЛ как «...заболевание, характеризуемое частично необратимым ограничением воздушного потока. Ограничение воздушного потока, как правило, имеет неуклонно прогрессирующий характер и вызвано аномальной воспалительной реакцией легочной ткани на раздражение различными патогенными частицами и газами...». Способствующим развитию данного 